\title{
THE USE OF NECESSITAS NON HABET LEGEM AND WEDERSPANNINGHEID IN LAW ENFORCEMENT FOR COVID-19 VACCINATION IN INDONESIA
}

\author{
*Moch. Marsa Taufiqurrohman, **Muhammad Toriq Fahri, **Robi Kurnia Wijaya, ***I Gede Putu Wiranata \\ * Former Student of Faculty of Law of Universitas Jember, Jawa Timur; \\ **Public Prosecutor of Kejaksanaan Negeri Banyuwangi, Jawa Timur; \\ ****Police Officer in Kepolisian Resor Kota Banyuwangi, Jawa Timur. \\ Corresponding author. Email: mochmarsat@gmail.com
}

Paper received on: 14-08-2021; Revised on: 23-10-2021; Approved to be published on: 09-11-2021

DOI: http://dx.doi.org/10.30641/dejure.2021.V21.473-488

\begin{abstract}
The majority of scientific research in the world agrees that vaccination is a vital instrument that aims to solve the problem of the Covid-19 pandemic. In achieving this goal, the government is trying to ensure that vaccinations run as they should. Even though it is regulated in laws and regulations, the enforcement of vaccination law is not easy to implement. This article aims to examine the formulation of the legal basis that can ensure effective enforcement of vaccination law in Indonesia. By using normative legal research, this study aims to answer several problems. First, is vaccination a right or obligation for every citizen? Second, what are the legal bases that can be used to enforce the vaccination law in Indonesia? Third, what is the state's responsibility for adverse events following vaccination in return for the vaccination obligation? This article provides a view that the principle of emergency reason does not know the law (necessitas non habet legem) can be an indicator of a shift in vaccination status which was originally only a right to become obligation. In addition, the wederspanningheid article in the Criminal Code (KUHP) regarding resistance to officers carrying out state obligations can be the legal basis for enforcing vaccination law. Furthermore, the enforcement of vaccination law must also go hand in hand with the state's responsibility for adverse events following vaccination. Responsibilities can be in the form of vaccine testing, treatment, care, and court lawsuits if there is a default or unlawful act.
\end{abstract}

Keywords: necessitas non habet legem; wederspanningheid; vaccination; covid-19; law enforcement

\section{INTRODUCTION}

Since the UK first became a pioneer in vaccinating in early December $2020,{ }^{1}$ other countries including Indonesia began to follow to make vaccination programs for their citizens. There is almost no scientific research in the world that denies the existence of vaccination as a vital and main instrument, making vaccination agreed upon as an effective way to solve the problem of the Covid- $19^{2}$ pandemic. This, in its development, has made vaccination a serious issue to be considered for countries affected by Covid-19.

The vaccination program is aimed at breaking the chain of transmission. The majority of scientific research in the world agrees that

\footnotetext{
"Negara-negara yang telah memulai vaksinasi Covid19," BBC News Indonesia, n.d., accessed August 14, 2021, https://www.bbc.com/indonesia/ dunia55394914.

2 Marc Lipsitch and Natalie E. Dean, "Understanding COVID-19 Vaccine Efficacy," Science 370, no. 6518 (2020): 24 .
}

vaccination can reduce the number of patients and reduce the risk of death from Covid-19, as well as form herd immunity. ${ }^{3}$ However, it is not without problems, the process of distributing vaccinations in Indonesia actually encounters obstacles. The emergence of doubts to negative perceptions of the Covid-19 vaccine has made the government start thinking about a repressive approach in meeting vaccine targets. This repressive approach has sparked debate, some argue that the vaccination obligation is a form of coercion which is a violation of human rights. ${ }^{4}$ On the other hand, there is an argument that repressive measures are needed in response to the low level of compliance and

\footnotetext{
Jerome H. Kim, Florian Marks, and John D. Clemens, "Looking beyond COVID-19 Vaccine Phase 3 Trials," Nature medicine 27, no. 2 (2021): 19.

4 "Natalius Pigai: Menolak Vaksin Covid-19 Itu Hak Asasi Rakyat," suara.com, last modified January 12, 2021, accessed August 12, 2021, https://hits.suara. com/read/2021/o1/12/172951/natalius-pigai-menolakvaksin-Covid-19-itu-hak-asasi-rakyat.
} 
willingness of the community to the vaccination program. ${ }^{5}$

This issue has triggered legal scholars to create discourses and find effective solutions in enforcing the Covid-19 vaccination law in Indonesia. Considering that the Covid-19 pandemic has caused multidimensional crises in various sectors, especially the health and economic sectors ${ }^{6}$, an effective strategy is needed to resolve existing problems, especially using the right approach and law enforcement.

The discourse on this issue presents several questions which this article will answer. First, is vaccination a right or obligation for every citizen? Second, what are the legal bases that can be used to enforce the vaccination law in Indonesia? Third, what is the state's responsibility for adverse events following vaccination in return for the Covid-19 vaccination obligation?

This article aims to examine the formulation of legal bases that can be used by the government to achieve vaccination targets. This article also aims to ensure how enforcement of vaccination law in Indonesia can run effectively.

Furthermore, this article would like to provide a view that the emergency reason that does not know the law (necessitas non habet legem) can be a main indicator of the shift in vaccination status which was originally only a right or voluntary to become obligation. In addition, the wederspanningheid article in the Criminal Code (KUHP) which makes resistance to officers carrying out state obligations can be the legal basis for enforcing the Covid-19 vaccination law in Indonesia.

So far, there has been no similar research that has analyzed in depth the application of the principle of necessitas non habet legem and the use of the wederspanningheid article as the right legal basis in the context of enforcing the Covid19 vaccination law in Indonesia. This paper seeks to further analyze the government's basis for setting criminal rules for people who refuse

5 Marulak Pardede, "Aspek Hukum Kekarantinaan Kesehatan Dan Perlindungan Konsumen Dalam Penanggulangan Pandemi Covid-19," Jurnal Penelitian Hukum De Jure 21, no. 1 (2021): 24.

6 "Coronavirus Disease (COVID-19) - World Health Organization," accessed August 11, 2021, https:// w w w.who.in t/em ergen cies/ diseas es/novelcoronavirus-2019. the vaccination program and protection after the Covid-19 vaccination.

To achieve this goal, this paper will be structured as follows. After the introduction and research method, the next section will discuss the rights and obligations of vaccination, as well as the use of the wederspanningheid article and necessitas non habet legem in the issue of the enforcement of Covid-19 vaccination law. Furthermore, the state's responsibility for adverse events following vaccination will be explained as a right of the Covid-19 vaccination obligation. The last section will describe the conclusions and follow-up or suggestions regarding the ideas that have been described.

\section{RESEARCHMETHOD}

This research used doctrinal normative legal research in collaboration with the Reform Oriented Research method. Normative legal research includes research on legal products, legal principles, legal systematics, legal synchronization, both vertically and horizontally, legal comparisons including looking at the history of existing laws.

Doctrinal research was conducted to examine policies regarding the enforcement of Covid-19 vaccination law in Indonesia. This research was started by looking at the existing law (doctrinal), then followed by consideration of the problems that affect the law, as well as the underlying legal politics.

This research also incorporated the Reform Oriented Research method. As this method is carried out to evaluate the feasibility of existing rules and recommend changes to the rules that are deemed necessary. This model is based on a legal reform research methodology to provide advice on changes to existing laws. In the end, this model directs researchers to propose a conception of the legal basis in the law enforcement process.

\section{DISCUSSION AND ANALYSIS}

\section{A. Rights and Obligations of Vaccination: Two-Pole Issues on Enforcement of Covid-19 Vaccination Law}

Vaccination itself according to Article 1 Number 3 of the Regulation of the Minister of Health Number 23 Year 2018 concerning Services and Issuance of International Vaccination 
Certificates means "The provision of vaccines that are specifically given in order to actively generate or increase a person's immunity against a disease, so that if one day they are exposed to the disease they will not get sick or only experience mild illness and will not be a source of transmission." Meanwhile, Article 1 Number 2 of the Regulation of the Minister of Health (Permenkes) Number 12 Year 2017 concerning the Implementation of Immunization explains that vaccines are biological products containing antigens in the form of dead or living microorganisms that are attenuated, still intact or parts thereof, or in the form of microorganism toxins processed into toxoids or recombinant proteins, which are added by other substances, which when given to a person will cause active specific immunity against certain diseases.

Specifically for the implementation of the Covid-19 vaccination, the Government regulates through Presidential Regulation Number 99 Year 2020 concerning Vaccine Procurement and Vaccination Implementation in the Context of Overcoming the Covid-19 Pandemic. Through Regulation of the Minister of Health No. 84 Year 2020 concerning the Implementation of Vaccination in the Context of Overcoming the Covid-19 Pandemic, the schedule and stages of vaccination are regulated.

Questions regarding the implementation of vaccination in Indonesia led to a discourse about two poles of different views on the existence of vaccines. This difference of opinion is regarding the question, is vaccination a right or an obligation? Furthermore, it turns out that the difference in opinion is not only limited to right and obligation, but also whether being vaccinated is something that is compulsory or voluntary?

One pole affirms that being vaccinated is part of the citizens' right to health. As this is not only guaranteed by the 1945 Constitution of the Republic of Indonesia (UUD NRI 1945), but also by Law Number 36 Year 2009 concerning Health. Article 28 I Paragraph (1) of the 1945 Constitution affirms that everyone has the right to live in physical and spiritual prosperity, to have a place to live, and to have a good and healthy living environment and have the right to obtain health services. Citizens' right to health is also reaffirmed in Articles 4-8 of the Health Law. Article 5 Paragraph (3) states that everyone has the right to independently and responsibly determine the health services needed for themselves. On the other hand, the other pole sees the rejection of the vaccination program as an act that can be subject to sanctions, including criminal sanctions.

\section{Figure 1. Comparison of Vaccination Regulation} as Right and Obligation

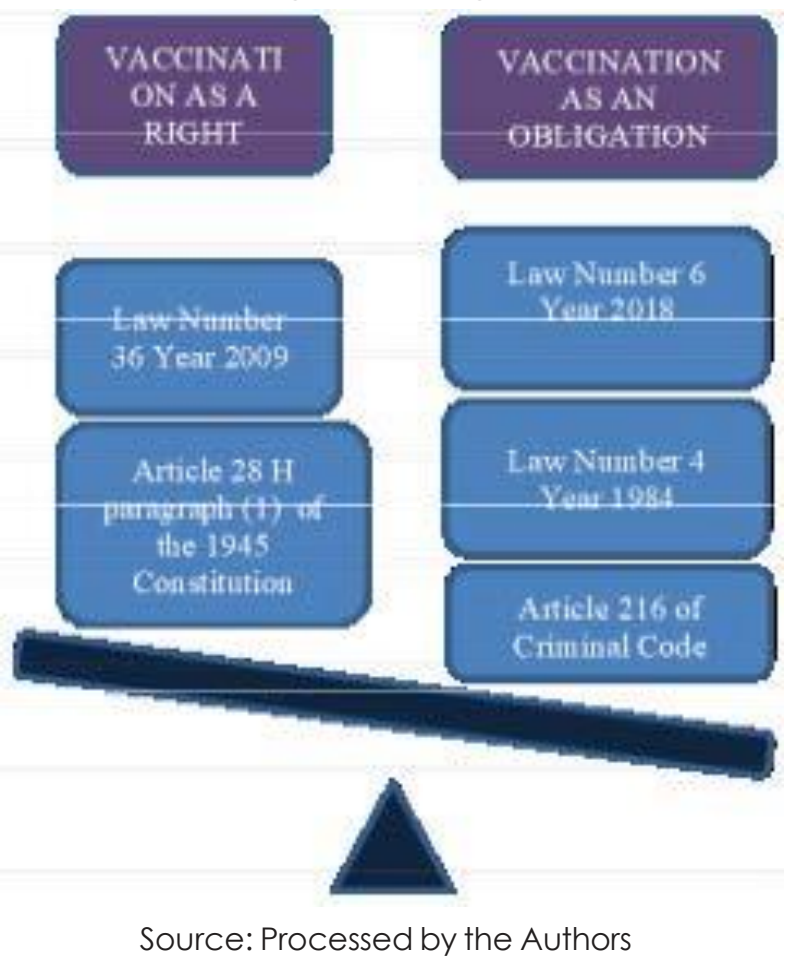

To answer the question at the beginning, it is necessary to review each pole. The first pole uses Article 28H Paragraph (1) of the 1945 Constitution of the Republic of Indonesia and Law Number 36 Year 2009 concerning Health as the bases for the assumption of vaccination as a right.

Article 28H Paragraph (1) confirms that everyone has the right to live in physical and spiritual prosperity, to have a place to live, and to have a good and healthy living environment and have the right to obtain health services. ${ }^{7}$ Then it is further regulated in Law Number 36 Year 2009 concerning Health. Article 5 Paragraph (3) states that "Everyone has the right to independently and responsibly determine the health services needed for themselves". Furthermore, Article 8 of the Health Law states "Everyone has the right to obtain information about his/her health data including actions and treatments that have been

\footnotetext{
I. Nyoman Prabu Buana Rumiartha, "Makna Hukum Pada Prinsip Tata Kelola Perspektif Pengadaan Vaksin Dan Pelaksanaan Vaksinasi Covid-19," Jurnal Ilmiah Raad Kertha 4, no. 1 (2021): 6-8.
} 
or will be received from health workers." Then Article 56 Paragraph (1) of the Health Law states that "Everyone has the right to accept or reject part or all of the relief measures that will be given to them after receiving and fully understanding the information regarding the measures." Therefore, it can be concluded that everyone has the right to independently and responsibly determine the health services needed for themselves. ${ }^{8}$

On the other hand, the other pole sees that rejection of vaccination is an act that can be subject to sanctions, including criminal sanctions. ${ }^{9}$ This is based on Law Number 6 Year 2018 concerning Health Quarantine, Law Number 4 Year 1984 concerning Outbreaks of Infectious Diseases, and Article 216 of the Criminal Code.

It should be noted that there is an exception to Article 56 Paragraph (1) of the Health Law, namely the right to accept or reject does not apply to patients whose diseases can quickly spread to the wider community. This provision is contained in Article 56 Paragraph (2) letter a of the Health Law. With this, it becomes clear that the Covid-19 vaccination is an obligation. This can be seen from Presidential Regulation Number 14 Year 2021. Article 13A Paragraph (2) and Paragraph (4) states that every person who has been designated as a target recipient of the Covid-19 vaccine based on data collection conducted by the Ministry of Health must follow the vaccination. If they do not follow the vaccination and they are not those who are exempted, the person may be subject to administrative sanctions in the form of: postponement or termination of the provision of social security or social aid; postponement or termination of government administration services; and fines. This Presidential Regulation delegates ministries, agencies, regional governments, or business entities in accordance with their authority to regulate the sanctions.

The government has determined that vaccination is an obligation so that rejection of vaccination efforts is considered not to comply

8 M. Ali Masnun, Eny Sulistyowati, and Irfa Ronaboyd, "Pelindungan Hukum Atas Vaksin Covid-19 Dan Tanggung Jawab Negara Pemenuhan Vaksin Dalam Mewujudkan Negara Kesejahteraan,” DiH: Jurnal Ilmu Hukum 17, no. 1 (2021): 35-37.

9 Rumiartha, "Makna Hukum Pada Prinsip Tata Kelola Perspektif Pengadaan Vaksin Dan Pelaksanaan Vaksinasi Covid-19," 40. with the implementation of health quarantine. This is stated in Article 9 Paragraph (1) in conjunction with Article 93 of Law Number 6 Year 2018 concerning Health Quarantine which reads "Anyone who does not comply with the implementation of Health Quarantine as referred to in Article 9 Paragraph (1) and/or hinders the implementation of the Health Quarantine causing a Public Health Emergency shall be sentenced to imprisonment for a maximum of 1 (one) year and/or a fine of a maximum of IDR 100,000,000.00 (one hundred million rupiah)." In addition, this provision is also regulated in Article 14 Paragraph (1) of Law Number 4 Year 1984 concerning Outbreaks of Infectious Diseases which states "Anyone who deliberately hinders the implementation of epidemic control as regulated in this Law is subject to imprisonment for a maximum of 1 year and/or a fine of a maximum of IDR 1 million."

In fact, there are also those who reason the obligation of vaccination by mentioning the possibility of using Article 216 of the Criminal Code if there are people who prevent medical officers or other officers from carrying out vaccination duties. Article 216 Paragraph (1) of the Criminal Code threatens to impose sanctions of 4 months and 2 weeks on anyone who deliberately does not comply with orders or strong requests made according to laws and regulations by civil servants who are required to supervise or by civil servants who are required or authorized to carry out examination of criminal act. ${ }^{10}$ Likewise, whoever intentionally prevents, hinders or thwarts a civil servant's work to carry out laws and regulations. Therefore, a person who does not carry out the order to follow the vaccination or hinders vaccination program officers can be punished according to this article. ${ }^{11}$

Furthermore, if it is connected to the aspect of human rights, then a right will automatically result in the consequences of obligations from each person to others. Therefore, human rights are directly proportional to one's basic obligations

\footnotetext{
10 Muhmmad Zainuddin and Siti Nur Umariyah Febriyanti, "Perlindungan Hukum Terhadap Relawan Uji Klinis Vaksin Covid-19," Jurnal Ilmiah Dunia Hukum (2021): 134-135.

" Rumiartha, "Makna Hukum Pada Prinsip Tata Kelola Perspektif Pengadaan Vaksin Dan Pelaksanaan Vaksinasi Covid-19," 8.
} 
to others and to society as a whole..$^{12}$ This is in accordance with Article 69 of Law Number 39 Year 1999 concerning Human Rights: "Every human right of a person creates a basic obligation and responsibility to respect the human rights of others reciprocally and it is the duty of the government to respect, protect, uphold, and advance it. Therefore, it can be concluded that the right to vaccination is closely related to the emergence of vaccination obligation for others.

The arising questions related to the issue of right and obligation above lead to a conclusion. That there are at least three norms that can be used at once to strengthen the view of vaccination as an obligation. The government guarantees the protection, promotion, enforcement and fulfillment of citizens' human rights to health and ensures the availability of safe, quality, effective, affordable and equitable immunization materials for the community (Article 153 of the Health Law). In return, what citizens must do is to respect the human rights of every citizen in the orderly life of society, nation and state (Article 28J Paragraph (1) of the 1945 Constitution) and participate in realizing, maintaining, and increasing the degree of personal and public health to the maximum (Article 9 of the Health Law).

B. Wederspanningheid article and Necessitas Non Habet Legem in Enforcement of Covid-19 Vaccination Law

1. Considering the Use of Necessitas Non Habet Legem as a Principle for Enforcement of Covid-19 Vaccination Law in Indonesia

In enforcing the Covid-19 vaccination law in Indonesia, the right 'legal basis' is needed to legitimize the enforcement of the law. If the positive laws and regulations that apply in Indonesia cannot legitimize the enforcement of the Covid-19 vaccination law, then another legal basis is needed to legitimize it.

Ad Recte docendum oportet primum inquirere nomina, quia rerum cognitio a nominimbus rerum dependet, ${ }^{13}$ is a classical legal postulate which means that to understand a legal concept one must

12 Simon Simon etal., "Participation of Religious Leaders in Helping the Success of the Government's COVID-19 Vaccination Program," Evangelikal: Jurnal Teologi Injili dan Pembinaan Warga Jemaat 5, no. 2 (2021): 236-237.

13 Eddy OS Hiariej, Prinsip-Prinsip Hukum Pidana (Cahaya Atma Pustaka, 2016), 2. start from a definition. ${ }^{14}$ On this basis, in order to understand what legal basis can be used, we must first understand the definition of the law itself, and its difference with laws and regulation.

Law covers something broad, such as principles, doctrines, justice, expedience, order, and certainty itself, while laws and regulations only cover the rules made by the legislature and the executive in force. ${ }^{15}$ Therefore, if we cannot find an appropriate and binding 'legal basis' for the enforcement of the Covid-19 vaccination law through laws and regulations, then we can use the legal principles that are part of the scope of law as the 'legal basis' itself.

In relation to the enforcement of the vaccination law, a question arises: can the government make extraordinary efforts, in other words, efforts that are outside the corridor and procedures of law in force on an emergency basis to protect the interests of the people? In a sense, is the government allowed to take measures outside the corridor of law in force in order to protect the people from the dangers of the Covid-19 pandemic?

In legal studies, there is the principle of necessitas non habet legem which means that an emergency situation does not know the law. ${ }^{16}$ This principle can allow the ruler to impose a policy on the grounds of an emergency. Further explanation can be seen in the following table:

Table 1. The Meaning of Necessitas Non Habet Legem

\begin{tabular}{|c|c|}
\hline \multicolumn{2}{|c|}{ Necessitas Non Habet Lagem } \\
\hline Oxford Reference & Law Times Journal \\
\hline $\begin{array}{l}\text { Necessity has no law. } \\
\text { A maxim meaning. }\end{array}$ & $\begin{array}{l}\text { Necessitas non habet legem } \\
\text { is an old age maxim which } \\
\text { means necessity know } \\
\text { no law. A person may } \\
\text { sometimes have to succumb } \\
\text { to the pressure of other party } \\
\text { to the bargain who is on a } \\
\text { stronger position. This kind } \\
\text { of bargain can be referred } \\
\text { to as bargain under undue } \\
\text { influence. }\end{array}$ \\
\hline
\end{tabular}

Source: Alan Brudner: A Theory of Necessity

${ }^{14}$ Peter Jeremiah Setiawan, Xavier Nugraha, and Moch Marsa Taufiqurrohman, "Penggunaan Daluwarsa Sebagai Dasar Gugatan Praperadilan Di Indonesia: Antara Formil Atau Materiil," Volksgeist: Jurnal Ilmu Hukum dan Konstitusi 3, no. 2 (2020): 2.

15 S. H. Barda Nawawi Arief, Masalah Penegakan Hukum Dan Kebijakan Hukum Pidana Dalam Penanggulangan Kejahatan (Prenada Media, 2018), 79.

16 M. N. Campagnoli, "Necessitas Non Habet Legem? Sicurezza vs. Libertà" (2017): 18. 
Referring to the explanation above, in a juridical study of health workers who provide vaccination services, in principle, the principle of necessitas non habet legem can also be applied. Necessitas non habet legem is an old saying (maxim) which means necessity/emergency does not know the law. This means that in the application of this principle, in an emergency, one sometimes has to give in to pressure from the other party with bargain who is in a stronger position. ${ }^{17}$ This kind of bargaining can be termed bargaining under undue influence. ${ }^{18}$ This also applies to law enforcement officers. Therefore, in the practice of enforcement of Covid-19 vaccination law, it is possible that there are deviations from certain legal rules that are not subject to sanctions, namely the right or choice to be vaccinated or not. In this case, there are deviations or exceptions (de uitzonderingen bevestigen de regel). ${ }^{19}$

Even in legal studies, it is known that there are violations of the law committed in certain circumstances, which in principle can be grouped into two, namely: ${ }^{20}$ First, actions that are essentially violations of legal rules, but are not subject to sanctions because they are justified or have justification (rechtvaardigingsground). ${ }^{21}$ In this context, the actions essentially violate the legal rules that are permitted. These actions include emergency situations, forced defense, statutory provisions and office orders..$^{22}$ Second, actions that are essentially violations of legal rules, but are not subject to sanctions because the perpetrator of the violation is freed from guilt (schuldopheffingsgrond). ${ }^{23}$ These actions occur because of what is called force majeure, overmacht

${ }^{17}$ Alan Brudner, "A Theory of Necessity," Oxford Journal of Legal Studies 7, no. 3 (1987): 144.

18 Alessandro Candido, "Necessitas Non Habet Legem? Pandemia e Limiti Alla Libertà Di Circolazione," Quaderni costituzionali 40, no. 2 (2020): 4.

19 Muhamad Beni Kurniawan, "Politik Hukum Pemerintah Dalam Penanganan Pandemi Covid-19 Ditinjau Dari Perspektif Hak Asasi Atas Kesehatan," Jurnal HAM 12, no. 1 (2021): 40-43.

2o Ibid., 48-49.

${ }^{21}$ Andi Hamzah, Hukum Pidana Indonesia (Sinar Grafika, 2017), 104.

22 Suharyo Suharyo, "Aspek Hukum Surat Keterangan Dokter Dalam Sistem Peradilan Pidana (Pemberantasan Tindak Pidana Korupsi pada Era Covid-19)," Jurnal Penelitian Hukum De Jure 20, no. 3 (September 29, 2020): 9 .

${ }_{23}$ Hamzah, Hukum Pidana Indonesia, 105. or a state of coercion or emergency, which is a condition or force beyond human ability.

The emergency contained in the principle of necessitas non habet legem also lies in the Government's obligation to save the people by taking legal action. In a sense, if there are people who do not want to be vaccinated, such an attitude can harm others. ${ }^{24}$ Therefore, an attitude that can endanger itself can also be interpreted as a form of emergency.

The principle of necessitas non habet legem is also related to the principle of saluspopuli suprema lex esto, which means that the safety of the people is the highest law. ${ }^{25}$ In order to save the people, the government can use coercive legal policies in an emergency. ${ }^{26}$ In this case, the government sets public safety as a top priority. ${ }^{27}$ The state can therefore demonstrate an urgent need with regard to the people and a legally justifiable reason to limit individual rights. ${ }^{28}$ Therefore, the state, especially the government, is obliged to realize welfare in the health sector which is the basic right of every citizen. ${ }^{29}$

24 Yusuf Abdul Rahman, "Vaksinasi Massal Covid-19 Sebagai Sebuah Upaya Masyarakat Dalam Melaksanakan Kepatuhan Hukum (Obedience Law)," Khazanah Hukum 3, no. 2 (2021): 21.

25 Azis Ahmad Sodik, "JUSTICIABELEN: Penegakan Hukum Di Institusi Pengadilan Dalam Menghadapi Pandemi Covid-19," Khazanah Hukum 2, no. 2 (2020): 57.

26 Suharyo Suharyo, "The Prospect of the Existence of National Criminal Code in a Democratic State in Indonesia during the Covid-19 Pandemic," Jurnal Penelitian Hukum De Jure 21, no. 3 (September 28, 2021): 7 .

27 Rizki Bagus Prasetio, "Pandemi Covid-19: Perspektif Hukum Tata Negara Darurat dan Perlindungan HAM," Jurnal Ilmiah Kebijakan Hukum 15, no. 2 (July 26, 2021): 11.

28 Ari Wirya Dinata and M Yusuf Akbar, "Pembatasan Hak Untuk Bergerak (Right to Move) melalui Larangan Masuk dan Pembatasan Perjalanan selama Penyebaran Virus COVID-19 menurut Hukum Internasional dan Hukum Indonesia," Jurnal HAM 12, no. 2 (August 26, 2021): 10 .

29 Otih Handayani, "Kontroversi Sanksi Denda Pada Vaksinasi Covid-19 Dalam Perspektif Undang-Undang No. 36 Tahun 2009 Tentang Kesehatan," KRTHA BHAYANGKARA 15, no. 1 (2021): 85-87. 
2. Questioning the Appropriateness of Using Wederspanningheid Article in Taking Action against Public Resistance to Vaccination Obligation

Law enforcement efforts carried out by officers during the Covid-19 pandemic emergency are not a piece of cake..$^{30}$ In addition to the wide coverage area and the limitations of the apparatus, there is also resistance from parties who are required to comply with the terms and obligations based on the policies issued. ${ }^{31}$ It is not surprising that the policies issued during the Community Activity Restrictions (PPKM) period saw the aspect of law enforcement. ${ }^{32}$ Consider, for example, the spirit of law enforcement contained in Presidential Regulation Number 14 Year 2021 concerning Amendment to Presidential Regulation Number 99 Year 2020 concerning Vaccine Procurement and Vaccination Implementation in the Context of Overcoming the Corona Virus Disease 2019 (Covid-19) Pandemic. If a person has been determined as a vaccine recipient, and he does not follow the vaccination without a valid reason, the person is subject to administrative and criminal sanctions.

Official statements to impose sanctions on violators do not completely eliminate violations during the pandemic emergency. In fact, recently there was a riot during an emergency PPKM raid in East Java. Residents who did not accept to be disciplined fought the officers who were carrying out their duties. Officers arrested a shop owner who was suspected of provoking residents. The Resort Police Chief of Tanjung Perak Port, Surabaya, told the media that the suspect would be subject to Article 212 of the Criminal Code for resisting officers who were carrying out judicial operation duties. ${ }^{33}$

3o Marulak Pardede, “Aspek Hukum Kekarantinaan Kesehatan dan Perlindungan Konsumen dalam Penanggulangan Pandemi Covid-19," Jurnal Penelitian Hukum De Jure 21, no. 1 (February 22, 2021): 6.

${ }_{31} \quad$ Mei Susanto and Teguh Tresna Puja Asmara, "Ekonomi versus Hak Asasi Manusia dalam Penanganan Covid19: Dikotomi atau Harmonisasi," Jurnal HAM 11, no. 2 (August 28, 2020): 2.

32 Kurniawan, "Politik Hukum Pemerintah Dalam Penanganan Pandemi Covid-19 Ditinjau Dari Perspektif Hak Asasi Atas Kesehatan," 38-40.

33 Amir Baihaqi, "Kericuhan Operasi PPKM Darurat di Surabaya Berawal dari Provokasi Pemilik Warkop," detiknews, accessed August 13, 2021, https://news. detik.com/berita-jawa-timur/d-5639511/kericuhan-
In the aforesaid case the police used Article 212 of the Criminal Code. This provision is about resistance which in Dutch is called wederspanningheid. Andi Hamzah states that wederspanningheid contains the provision "Anyone with violence or threats of violence fights an official who is carrying out a legitimate task, or a person who according to statutory obligations or at the request of a civil servant provides assistance to the official, is subject to, for fighting a civil servant, imprisonment for a maximum of one year and four months or a fine of a maximum of four thousand five hundred rupiah." ${ }^{34}$

The question that arises then is, in enforcing the Covid-19 vaccination law, can the government use the wederspanningheid Article as a sanction for those who refuse or violate vaccination obligation? Can refusal to vaccination obligation in an emergency period be considered as resistance as stated in Article 212 of the Criminal Code?

Resistance in Dutch is called wederspanningheid. This term is taken from a keyword in Article 212 of the Criminal Code. In Dutch the formulation of this article is: "Hij diezich met gewek og bedreiging met geweld verzet tegeneen ombtenoor werzoom in de rechmotigeuitoefening zijner bediening, of tegen personen die hem doorbij krechtens wettelijke verplichting of op zijn verzoek bijstond verlenen, wordt, ols schuldig oon wedersponningheid, gestroft met gevongensistrofvon ten hoogste eenj oor en vier moonden of geldboete van ten hoogste vier duizen en vijf honderd gulden." This formulation was then translated by various Indonesian authors as seen in the following table.

Table 2. The meaning of Wederspanningheid in the Criminal Code

\begin{tabular}{|c|c|}
\hline Criminal Code Versions & Content \\
\hline Moeljatno (1994) & $\begin{array}{l}\text { Any person who with violence } \\
\text { or threat of violence fights an } \\
\text { official who is carrying out } \\
\text { legitimate duties, or a person } \\
\text { who according to statutory } \\
\text { obligations or at the request of an } \\
\text { official provides assistance to the } \\
\text { official, is subject to, for fighting } \\
\text { an official, imprisonment for a } \\
\text { maximum of one year and four } \\
\text { months or a fine of a maximum } \\
\text { of three hundred rupiah. }\end{array}$ \\
\hline
\end{tabular}

operasi-ppkm-darurat-di-surabaya-berawal-dariprovokasi-pemilik-warkop.

34 Andi Hamzah, Hukum Pidana Indonesia (Jakarta: Sinar Grafika, 2017), 47-48.

The Use of Necessitas Non Habet Legem Moch. Marsa Taufiqurrohman, Muhammad Toriq Fahri, Robi Kurnia Wijaya, I Gede Putu Wiranata 


\begin{tabular}{ll}
\hline National Law & Any person who with violence \\
Development Agency & or threat of violence fights an \\
official who is carrying out & legitimate duties, or a person \\
& who according to statutory \\
& obligations or at the request of an \\
& official provides assistance to the \\
& official, is subject to, for fighting \\
& an official, imprisonment for a \\
& maximum of one year and four \\
& months or a fine of a maximum \\
& of four thousand five hundred \\
& rupiah. \\
Any person who with violence \\
or threat of violence fights an \\
official who is carrying out \\
legitimate duties, or a person who \\
according to statutory obligations \\
or at the request of a civil servant \\
provides assistance to the civil \\
servant, is subject to, for fighting \\
a civil servant, imprisonment for \\
a maximum of one year and four \\
months or a fine of a maximum \\
of four thousand five hundred \\
rupiah.
\end{tabular}

There are three objective elements that can be found in Article 212 of the Criminal Code. First, regarding action that can be punished, namely fighting with violence or with threats of violence (met geweld of bedreidiging met geweld zich verzetten). ${ }^{35}$ The action that is prohibited by law is to fight. The resistance is carried out either through violence (such as hitting, kicking, and so on) or by threats of violence (for example: threatening words, sentences of threat to kill, and so on). ${ }^{36}$

In this first element, it can be concluded that if vaccination is an obligation for every citizen, then for citizens who refuse it, it can be interpreted mutatis mutandis as an act of resistance against vaccine officers who carry out their duties. That is, if it is interpreted a contrario, then if he does not refuse then he will not fight It can also be interpreted that refusing the vaccination obligation can be interpreted as an act of resistance as stated in Article 212 of the Criminal Code. This means that the refusal of the vaccination obligation can be subject to the wederspanningheid article.

Furthermore, a question arises: can resistance in the form of refusal of the vaccination

35 P. M. Schuyt, "Het Bepalen van de Straf: Een Taak van de Rechter," Trema. Straftoemetingsbulletin 32, no. 1 (2009): 13 .

${ }_{36}$ Zainuddin and Febriyanti, "Perlindungan Hukum Terhadap Relawan Uji Klinis Vaksin Covid-19,” 136. program carried out without violence be subject to the wederspanningheid article? It should be emphasized, that the tone of voice and the sentences spoken by a person seem to be very important to assess. This can be seen in the Supreme Court Decision No. $160 \mathrm{~K} / \mathrm{Pid} / 2015$ dated May 13, 2015. The Supreme Court Justice stated that the sentence spoken by the defendant to a land surveyor at the National Land Agency (BPN) was not a threat. Sentences from the defendant to witness-victim namely a civil servant who was carrying out his duties: "Sir, don't survey this land. This land is mine, because I have SPPT. If you dare to survey, you must be responsible for your performance!" were not spoken aloud. According to the panel, the witness-victim stopped the survey not because of a threat, but because the defendant showed SPPT (Notification of Tax Due) as evidence. The words spoken by the defendant by showing the SPPT were to defend his rights. Therefore, all forms of refusal, even if it is only speech and without violence, if it can be interpreted as resistance, then the perpetrator can be subject to the wederspanningheid article.

The second element, the action is directed at a civil servant who is carrying out his official duties legally (tegen een ambtenaar werkzaam in de rechtmatige uitoefening zijner bediening). ${ }^{37}$ This element contains keywords: civil servant, carrying out duties, and legitimate duties. Some literature translates the word "ambtenaar" into "official". ${ }^{38}$ There is difference in the definition of the term 'ambtenaar' in the translation of the Criminal Code in Indonesia; some people maintain the definition as a civil servant, while the other interpret it as an official.

Regarding the definition of civil servant, Indonesian legislation has actually developed. Initially, the term civil servant referred to Article 92 of the Criminal Code which states that the designation of civil servant includes all people who are elected in elections held according to general regulations, and people who are not by choice a member of a legislature, government, or representative established by or on behalf of the government. ${ }^{39}$

\footnotetext{
37 Jeannifer Jeannifer, "Sanksi Pidana Terhadap Penolak Vaksin Covid-19 Di Indonesia," Al Qodiri: Jurnal Pendidikan, Sosial dan Keagamaan 19, no. 1 (2021): 167.

${ }^{8}$ Ibid., 166-168.

39 Pardede, "Aspek Hukum Kekarantinaan Kesehatan
} 
Indonesia once had Law Number 8 Year 1974 concerning the Principles of Civil Servant, as amended by Law Number 43 Year 1999. In this law, a civil servant is defined as every citizen of the Republic of Indonesia who has met the specified requirements, is appointed by an authorized official and is given duties in a state office, or given other state duties, and is paid according to the prevailing laws and regulations. This Law has been revoked by Law Number 5 Year 2014 concerning State Civil Apparatus.

In addition to identification as a civil servant or official, this element also contains clarity regarding 'carrying out legitimate duties.' A civil servant or official must have their respective duties in their position. The legitimacy of duties according to law is very important, and can be used for those being tried under Article 212 of the Criminal Code. ${ }^{40}$ According to R. Soesilo, if the civil servant is carrying out his duties illegally, people cannot be punished. ${ }^{41}$ Therefore, if a person wants to question what a civil servant does, then the validity of the task becomes a crucial point. Does the civil servant have a letter of assignment? Is the action taken is his authority? Is the execution of the task carried out in a lawful manner?

Third, the person who assists the civil servant in carrying out his official duties based on obligations under the law or at the request of the civil servant. This element adds that people who carry out certain tasks do not always have to be civil servants. ${ }^{42}$ The resistance may be directed at people who help civil servants carrying out their duties under statutory obligations, or at the request of civil servants or officials. ${ }^{43}$

In connection with the objectives or targets of the resistance carried out, both against civil servant vaccine officers and against people who were asked for help by the civil servant vaccine

Dan Perlindungan Konsumen Dalam Penanggulangan Pandemi Covid-19," 26-29.

40 Handayani, "Kontroversi Sanksi Denda Pada Vaksinasi Covid-19 Dalam Perspektif Undang-Undang No. 36 Tahun 2009 Tentang Kesehatan," 90-91.

${ }_{41}$ R. Soesilo and M. Karjadi, Kitab Undang-Undang Hukum Acara Pidana Dengan Penjelasan Resmi Dan Komentar (Bogor: Politeia, 1997), 91-94.

42 Rumiartha, "Makna Hukum Pada Prinsip Tata Kelola Perspektif Pengadaan Vaksin Dan Pelaksanaan Vaksinasi Covid-19," 8-9.

43 Kurniawan, "Politik Hukum Pemerintah Dalam Penanganan Pandemi Covid-19 Ditinjau Dari Perspektif Hak Asasi Atas Kesehatan," 40-42. officers, it is also important to state the decision of the Hoge Raad dated December 20, 1926. In the decision, to be seen as a resistance according to Article 212 of the Criminal Code, resistance can only be used to hinder an official action that has been taken (in the a quo law it is an act of vaccination), but can also be used to thwart the official action, or the official act cannot work properly, in this case the vaccination. ${ }^{44}$

Therefore, the imposition of this article is appropriate to enforce the vaccination obligation. The above elements are important to serve as parameters for the imposition of the wederspanningheid article in taking action against public resistance to the Covid-19 vaccination obligation. However, with a note that it must first be determined and ensured that the vaccine is an obligation for every citizen.

Nevertheless, it should be remembered that the legal nature of imposing criminal sanctions is a last resort (ultimum remedium) ${ }^{45}$ Therefore, sanctions are used as the last resort in law enforcement, if other law enforcement means no longer function. ${ }^{46}$ For example, dissemination by health workers, doctors, and paramedics is very important to create public awareness that vaccines are useful and can reduce transmission rate and prevent disease. If there is already a basic understanding from the public about the importance of vaccines, then actually, coercive efforts of law enforcement in the context of sanctions are not necessary. ${ }^{47}$

\section{State Responsibilities for Adverse Events Following Vaccination as Rights of Vaccination Obligation}

\section{Legal Protection against Adverse Events Following Vaccination}

When vaccination is made an obligation, and violators can be subject to sanctions, the state in this case the government must be able to ensure

44 Sodik, "JUSTICIABELEN," 58-63.

45 Handayani, "Kontroversi Sanksi Denda Pada Vaksinasi Covid-19 Dalam Perspektif Undang-Undang No. 36 Tahun 20o9 Tentang Kesehatan," 91-93.

46 Rumiartha, "Makna Hukum Pada Prinsip Tata Kelola Perspektif Pengadaan Vaksin Dan Pelaksanaan Vaksinasi Covid-19," 7-8.

47 Masnun, Sulistyowati, and Ronaboyd, "Pelindungan Hukum Atas Vaksin Covid-19 Dan Tanggung Jawab Negara Pemenuhan Vaksin Dalam Mewujudkan Negara Kesejahteraan," 51. 
that there is protection and state responsibility for citizens who feel aggrieved after carrying out their obligations.

Moreover, one of the main problems with vaccination today is the aspect of public trust in vaccines that will be used in the Covid-19 vaccination program. Moreover, previously there were often side effects from immunization carried out by health workers to the community. Although the side effects that occur by some parties are categorized as incidents, for immunization or mass vaccination, the potential for these incidents is even greater.

The Ministry of Health has issued Decree of the Minister of Health Number HK.01.07/ MENKES/9860/2020 concerning Determination of Vaccine Types for the Implementation of Covid-19 Vaccination. This regulation stipulates six types of Covid-19 vaccines that will be used in the implementation of vaccinations in Indonesia. The six vaccines are produced by Bio Farma, Sinovac, AstraZeneca, Sinopharm Moderna, and Pfizer. ${ }^{48}$ In Indonesia, a distribution permit or user approval is required during an emergency (Emergency Use Authorization) by the National Agency of Drug and Food Control (BPOM) to be able to carry out vaccinations. ${ }^{49}$

This is crucial, considering that some people still have doubts about the effectiveness of the six types of vaccines. But then, the next question arises regarding this, namely: is the vaccine guaranteed safe? And, what if there are negative effects of using vaccines that occur later and affect the general public?

If we look back, there are several records of problems after the implementation of vaccination. An example is the Adverse Events Following Immunization (AEFI). Complaints that arised regarding the symptoms of AEFI are quite diverse. Starting from pain in the body after immunization, loss of appetite, blurred vision, and even death after a few days. ${ }^{50}$

\footnotetext{
${ }^{48}$ Redaksi Halodoc, "6 Vaksin Corona yang Digunakan di Indonesia," halodoc, accessed August 13, 2021, https://www.halodoc.com/artikel/6-vaksin-coronayang-digunakan-di-indonesia.

49 Ibid.

${ }^{50}$ Agus Purwadianto, "Aspek Hukum KIPI (Kejadian Ikutan Pasca Imunisasi)," Sari Pediatri 2, no. 1 (2016): 11-13.
}

In recent years, there have been frequent lawsuits from patients who feel that they have been harmed. Commonly, they demand compensation due to faults or negligence made by doctors or health workers in carrying out their work. ${ }^{51}$ Although in the process there are difficulties in proving the faults and negligence of officers, various cases have been tried in court and have received attention from the health profession circle. ${ }^{52}$ It must be admitted that the issue of AEFI has also become one of the causes of doubt about the Covid-19 vaccine which is currently being pursued by the government.

Regulation of the Minister of Health Number 8 Year 2020 concerning Services and Issuance of International Vaccination Certificates has regulated the monitoring and overcoming adverse events following Covid-19 vaccination. Article 28 regulates that in the event of an adverse event following Covid-19 vaccination on a person receiving the Covid-19 vaccination, recording and reporting will be carried out as well as an investigation. On the results of this investigation, a field etiology study will be conducted by the Regional Committee for the Study and Countermeasures of Adverse Events Following Immunization and a causality study by the National Committee for the Study and Countermeasures of Adverse Events Following Immunization (National Committee for AEFI) which is determined in accordance with the provisions of laws and regulations..$^{53}$

Furthermore, Article 28 Paragraph (3) requires treatment and care in accordance with medical indications and health protocols. Meanwhile, if the results of the causality study find that the adverse event is influenced by the Covid-19 vaccine product, the BPOM will conduct sampling and testing in accordance with the provisions of laws and regulations.

The National Committee for AEFI stated that regarding AEFI cases that often occur in the community, the majority of the cases are caused by coincidences that are associated with recent

${ }^{51}$ Ibid., $18=19$.

52 Sri Rezeki S. Hadinegoro, "Kejadian Ikutan Pasca Imunisasi," Sari Pediatri 2, no. 1 (2016): 7.

53 Ahmad Juanda, "Perlindungan Hukum Pelaksana Imunisasi Dalam Kejadian Ikutan Pasca Imunisasi Di Kabupaten Sukabumi," Aktualita: Jurnal Hukum 1, no. 1 (2018): 17-19. 
immunizations. $^{54}$ Basically, vaccines cannot provide absolute protection against disease or side effects of immunization. However, vaccination measures at least provide greater protection when compared to no vaccination. Cases of AEFI in vaccination can occur if health workers or vaccinators do not carry out the procedures that should be in the vaccination stage. ${ }^{55}$

AEFI from a medical point of view is an empirical fact that is united in a phenomenon called medical action. AEFI is a side-effect and/ or adverse effect of medical action in the form of immunization. ${ }^{56}$ What is meant by medical action here is an intervention on the patient's body and soul in the context of prevention, specific protection, diagnostics, therapy, and rehabilitation for medical purposes. Immunization is a medical action in the aspect of prevention and specific protection aimed at patients or clients. ${ }^{57}$

Therefore, the legal relationship that exists in the act of immunization is a health workerclient relationship, which basically can remain or immediately turn into a doctor-patient relationship. In AEFI, the client who was previously healthy has turned sick, which even under certain circumstances, like the risk of other medical actions, can become sick, disabled, and fatal, so that a lawsuit from the victim (who was originally a client) also arises. ${ }^{58}$

AEFI cases, although very rare, can happen anywhere, to anyone and by any health worker. AEFI case can occur in mass immunization programs, but can also be found in individual immunization events. In mass immunization, it is numerically possible that AEFI will be revealed to the surface, some of which have the potential to become medical disputes. ${ }^{59}$

54 Tamardi Arief and Azhari Yahya, "Ganti Rugi Akibat Perbuatan Melawan Hukum Atas Kesalahan Tenaga Kesehatan Dalam Pelaksanaan Imunisasi," Jurnal Ilmiah Mahasiswa Bidang Hukum Keperdataan 2, no. 4 (2018): 848-853.

55 Hadinegoro, "Kejadian Ikutan Pasca Imunisasi," 8.

${ }_{56}$ Mohamad Hamsul Putra Daaliuwa, "Pengaruh Kejadian Ikutan Pasca Imunisasi Terhadap Kepatuhan Pemberian Imunisasi DPT/Hib Di Wilayah Kerja Puskesmas Tombulilato," Skripsi 1, no. 841415148 (2017): 7 .

57 Juanda, "Perlindungan Hukum Pelaksana Imunisasi Dalam Kejadian Ikutan Pasca Imunisasi Di Kabupaten Sukabumi," 20.

${ }_{58}$ Hadinegoro, "Kejadian Ikutan Pasca Imunisasi," 6-10.

59 Arief and Yahya, "Ganti Rugi Akibat Perbuatan
Actually, AEFI patients are still in the suspect category, because the Regulation of the Minister of Health Number 42 Year 2013 concerning the Implementation of Immunization has regulated that reports of suspected AEFI shall be handled by the Central National Committee for Study and Countermeasures of AEFI, Regional Committee for AEFI and Regency/Municipal AEFI Working Groups which will investigate in stages whether the AEFI is due to immunization or due to other causes. ${ }^{60}$

Therefore, immunization implementers should not have to worry too much because the results of investigation by the Regional Committee for AEFI will explain whether the alleged AEFI is proven due to an error or negligence of immunization implementers or other medical factors. If the results of the investigation state that the case is caused by other medical factors and not because of the causality of immunization, and if the patient does not accept the results of the investigation, then the patient has the right to ask the court to try the AEFI case that is detrimental to him. ${ }^{61}$

\section{Legal Responsibility for Adverse Events Following Vaccination}

Regarding the legal responsibilities of vaccination implementers, vaccination implementers who carry out vaccination services that are not in accordance with the Regulation of the Minister of Health Number 42 Year 2013 concerning the Implementation of Immunization will be subject to disciplinary punishment imposed on the relevant immunization implementer. ${ }^{62}$ Immunization implementers as immunization service providers and patients as immunization service recipients have legal liability based on this therapeutic transaction, if there is a lawsuit to hold health workers accountable.

The lawsuit is based on two legal bases, namely first, based on default as regulated in Article 1239 of the Civil Code. Second, based on unlawful acts in accordance with the provision

Melawan Hukum Atas Kesalahan Tenaga Kesehatan Dalam Pelaksanaan Imunisasi," 850-853.

6o Hadinegoro, "Kejadian Ikutan Pasca Imunisasi," 6-8.

61 Purwadianto, "Aspek Hukum KIPI (Kejadian Ikutan Pasca Imunisasi)," 15 .

62 Juanda, "Perlindungan Hukum Pelaksana Imunisasi Dalam Kejadian Ikutan Pasca Imunisasi Di Kabupaten Sukabumi," 20-21. 
of Article 1365 of the Civil Code. Patients' lawsuit against health workers occurs in the case of an alleged default in the implementation of immunization. ${ }^{63}$

Default in immunization services arises because of the actions of an immunization implementer in the form of giving immunization which is not in accordance with what was promised. This inappropriate service can be in the form of an act of carelessness or the result of negligence of the relevant immunization implementer so that it violates the therapeutic objectives. ${ }^{64}$

In a lawsuit on the basis of default, the two elements must first be proven by the existence of a therapeutic contract between the patient and the immunization implementer. Verification of the existence of a therapeutic contract can be done by the patient by submitting a medical record or with the consent of the medical action given by the patient.

Even in a therapeutic contract, with the existence of a medical card or by the arrival of the patient to the immunization implementer to ask for help, it can be considered that a therapeutic agreement has occurred. This is an implicit informed consent. It is recommended that before carrying out immunization, informed consent shall be given and it shall be signed by the patient or the patient's parent and the consent shall state that everything has been explained according to the applicable immunization regulations. ${ }^{65}$

For the second element, it must be proven by the existence of errors and/or negligence of the immunization implementer. To prove this, the patient must submit the fact that the immunization implementer who provided the immunization did not do what was promised and would be done in the therapeutic contract or the immunization implementer did what was promised but it was late, or the relevant immunization implementer performed the immunization not in accordance with what was promised, or the immunization implementer performed what according to the

${ }_{63}$ Purwadianto, "Aspek Hukum KIPI (Kejadian Ikutan Pasca Imunisasi)," 14-19.

${ }^{64}$ Arief and Yahya, "Ganti Rugi Akibat Perbuatan Melawan Hukum Atas Kesalahan Tenaga Kesehatan Dalam Pelaksanaan Imunisasi," 849-851.

${ }^{6}$ Juanda, "Perlindungan Hukum Pelaksana Imunisasi Dalam Kejadian Ikutan Pasca Imunisasi Di Kabupaten Sukabumi," 17-22. agreement must not be done. In order to be fulfilled, all the actions of immunization implementer above must have a causal relationship with the losses suffered by the patient. ${ }^{66}$

\section{CONCLUSION}

In achieving the vaccination target, there are several problems faced by the government in enforcing the Covid-19 vaccination law. First, there are two poles of difference regarding the Covid-19 vaccination: whether it is a right and voluntary or an obligation. In conclusion, the question is answered by the existence of three norms that can be used to strengthen the view of vaccination as an obligation at once, namely Article 153 of the Health Law, Article 28J Paragraph (1) of the 1945 Constitution, and Article 9 of the Health Law.

The second problem is related to the legal basis that can be used to enforce the vaccination law in Indonesia. The emergency reason that does not know the law (necessitas non habet legem) can be a major indicator of the shift in vaccination status which was originally only a right or voluntary to become an obligation. In addition, the wederspanningheid article in the Criminal Code (KUHP), by interpreting refusal as an act of resistance against officers carrying out state obligations, can be the legal basis for enforcing the Covid-19 vaccination law in Indonesia.

The third problem is related to the form of state responsibility for adverse events following vaccination in return for vaccination obligation. In order to guarantee the protection of citizens, the government has formulated a number of legal protections against adverse events following vaccination. First, there are recording and investigation, and sampling testing by BPOM. Second, providing treatment and care services according to medical indications and health protocols. Then, if it is not deemed sufficient, and there are patients who are further harmed, such as adverse events following vaccination of severe category, the patient in this case can file a lawsuit to the court on the basis of default and an unlawful act based on medical and legal facts.

\footnotetext{
${ }^{66}$ Putusan Pengadilan Ternate Nomor 53/Pdt.G/2019/PN Tte
} 


\section{SUGGESTION}

In line with the conclusions above, this paper would like to convey some suggestions. First, in responding to differences of opinion regarding the status of the right and obligation of Covid-19 vaccination, it is necessary to integrate the outbreak and pandemic handling regime through the renewal of the Epidemic and Infectious Diseases Law. This is intended so that the handling of outbreaks and pandemics in the future can be carried out comprehensively and not spatially and separately.

Second, in enforcing the Covid-19 vaccination law, it is necessary to update the Draft Criminal Code to emphasize law enforcement in the context of overcoming outbreaks and pandemics appropriately, concretely, and effectively. This suggestion is important, considering that the pandemic is a global issue that cannot be predicted when it will end, and has a high probability of reoccurring.

Third, considering that a given vaccination obligation must also come with the state's responsibility for adverse events following vaccination, the clause on the protection of citizens as a form of implementation of the constitutional mandate must also be included in the renewal of the Law on Outbreaks and Infectious Diseases, both civilly and administratively. In the end, the enforcement of the Covid-19 vaccination law can produce certainty, justice, and legal benefits as well as being effective and optimal in overcoming the Covid-19 pandemic.

\section{ACKNOWLEDGMENT}

The authors would like to thank for the support and guidance of all lecturers of the Postgraduate Program, Faculty of Law, University of Jember, so that this article can be completed properly. Especially to the Head of Office of the District Prosecutor General of Banyuwangi and the Banyuwangi City Resort Police Chief, the authors would like to thank for the support and permission in completing this article. Hopefully this article can have a significant effect on the authors' performance in the future, both for the Banyuwangi DistrictAttorney and the Banyuwangi City Resort Police.

\section{BIBLIOGRAPHY}

Arief, Tamardi, and Azhari Yahya. "Ganti Rugi Akibat Perbuatan Melawan Hukum Atas Kesalahan Tenaga Kesehatan Dalam Pelaksanaan Imunisasi." Jurnal Ilmiah Mahasiswa Bidang Hukum Keperdataan 2, no. 4 (2018): 846-854.

Baihaqi, Amir. "Kericuhan Operasi PPKM Darurat di Surabaya Berawal dari Provokasi Pemilik Warkop." detiknews. Accessed August 13, 2021. https://news.detik.com/berita-jawatimur/d-5639511/kericuhan-operasi-ppkmdarurat-di-surabaya-berawal-dari-provokasipemilik-warkop.

Barda Nawawi Arief, S. H. Masalah Penegakan Hukum Dan Kebijakan Hukum Pidana Dalam Penanggulangan Kejahatan. Prenada Media, 2018.

Brudner, Alan. "A Theory of Necessity." Oxford Journal of Legal Studies 7, no. 3 (1987): 339-368.

Campagnoli, M. N. "Necessitas Non Habet Legem? Sicurezza vs. Libertà" (2017).

Candido, Alessandro. "Necessitas Non Habet Legem? Pandemia e Limiti Alla Libertà Di Circolazione." Quaderni costituzionali 40, no. 2 (2020): 376-379.

DAALIUWA, MOHAMAD HAMSUL PUTRA. "Pengaruh Kejadian Ikutan Pasca Imunisasi Terhadap Kepatuhan Pemberian Imunisasi DPT/Hib Di Wilayah Kerja Puskesmas Tombulilato." Skripsi 1, no. 841415148 (2017).

Dinata, Ari Wirya, and $M$ Yusuf Akbar. "Pembatasan Hak Untuk Bergerak (Right to Move) melalui Larangan Masuk dan Pembatasan Perjalanan selama Penyebaran Virus COVID-19 menurut Hukum Internasional dan Hukum Indonesia." Jurnal HAM 12, no. 2 (August 26, 2021): 305.

Hadinegoro, Sri Rezeki S. "Kejadian Ikutan Pasca Imunisasi." Sari Pediatri 2, no. 1 (2016): $2-10$.

Halodoc, Redaksi. "6 Vaksin Corona yang Digunakan di Indonesia." halodoc. Accessed August 13, 2021. https://www.halodoc.com/ 
artikel/6-vaksin-corona-yang-digunakan-diindonesia.

Hamzah, Andi. Hukum Pidana Indonesia. Sinar Grafika, 2017.

Handayani, Otih. "Kontroversi Sanksi Denda Pada Vaksinasi Covid-19 Dalam Perspektif Undang-Undang No. 36 Tahun 2009 Tentang Kesehatan." KRTHA BHAYANGKARA 15, no. 1 (2021): 84-102.

Hiariej, Eddy OS. Prinsip-Prinsip Hukum Pidana. Cahaya Atma Pustaka, 2016.

Jeannifer, Jeannifer. "Sanksi Pidana Terhadap Penolak Vaksin Covid-19 Di Indonesia." Al Qodiri: Jurnal Pendidikan, Sosial dan Keagamaan 19, no. 1 (2021): 164-169.

Juanda, Ahmad. "Perlindungan Hukum Pelaksana Imunisasi Dalam Kejadian Ikutan Pasca Imunisasi Di Kabupaten Sukabumi." Aktualita: Jurnal Hukum 1, no. 1 (2018): 16-30.

Kim, Jerome H., Florian Marks, and John D. Clemens. "Looking beyond COVID-19 Vaccine Phase 3 Trials." Nature medicine 27, no. 2 (2021): 205-211.

Kurniawan, Muhamad Beni. "Politik Hukum Pemerintah Dalam Penanganan Pandemi Covid-19 Ditinjau Dari Perspektif Hak Asasi Atas Kesehatan." Jurnal HAM 12, no. 1 (2021): 37-56.

Lipsitch, Marc, and Natalie E. Dean. "Understanding COVID-19 Vaccine Efficacy." Science 370, no. 6518 (2020): 763-765.

Masnun, M. Ali, Eny Sulistyowati, and Irfa Ronaboyd. "Pelindungan Hukum Atas Vaksin Covid-19 Dan Tanggung Jawab Negara Pemenuhan Vaksin Dalam Mewujudkan Negara Kesejahteraan." DiH: Jurnal Ilmu Hukum 17, no. 1 (2021): 35-47.

Pardede, Marulak. "Aspek Hukum Kekarantinaan Kesehatan Dan Perlindungan Konsumen Dalam Penanggulangan Pandemi Covid-19." Jurnal Penelitian Hukum De Jure 21, no. 1 (2021): 23-44.

Pardede, Marulak. "Aspek Hukum Kekarantinaan Kesehatan dan Perlindungan Konsumen dalam Penanggulangan Pandemi Covid-19.”
Jurnal Penelitian Hukum De Jure 21, no. 1 (February 22, 2021): 23.

Prasetio, Rizki Bagus. "Pandemi Covid-19: Perspektif Hukum Tata Negara Darurat dan Perlindungan HAM." Jurnal Ilmiah Kebijakan Hukum 15, no. 2 (July 26, 2021): 327.

Purwadianto, Agus. "Aspek Hukum KIPI (Kejadian Ikutan Pasca Imunisasi)." Sari Pediatri 2, no. 1 (2016): 11-22.

Rahman, Yusuf Abdul. "Vaksinasi Massal Covid19 Sebagai Sebuah Upaya Masyarakat Dalam Melaksanakan Kepatuhan Hukum (Obedience Law)." Khazanah Hukum 3, no. 2 (2021).

Rumiartha, I. Nyoman Prabu Buana. "Makna Hukum Pada Prinsip Tata Kelola Perspektif Pengadaan Vaksin Dan Pelaksanaan Vaksinasi Covid-19." Jurnal Ilmiah Raad Kertha 4, no. 1 (2021): 1-9.

Schuyt, P. M. "Het Bepalen van de Straf: Een Taak van de Rechter." Trema. Straftoemetingsbulletin 32, no. 1 (2009): 13-16.

Setiawan, Peter Jeremiah, Xavier Nugraha, and Moch Marsa Taufiqurrohman. "Penggunaan Daluwarsa Sebagai Dasar Gugatan Praperadilan Di Indonesia: Antara Formil Atau Materiil." Volksgeist: Jurnal Ilmu Hukum dan Konstitusi 3, no. 2 (2020): 145161.

Simon, Simon, Alfons Renaldo Tampenawas, Joko Santoso, Astrid Maryam Yvonny Nainupu, Semuel Ruddy Angkouw, and Alvonce Poluan. "Participation of Religious Leaders in Helping the Success of the Government's COVID-19 Vaccination Program." Evangelikal: Jurnal Teologi Injili dan Pembinaan Warga Jemaat 5, no. 2 (2021): 234-245.

Sodik, Azis Ahmad. "JUSTICIABELEN: Penegakan Hukum Di Institusi Pengadilan Dalam Menghadapi Pandemi Covid-19." Khazanah Hukum 2, no. 2 (2020): 56-64.

Soesilo, R., and M. Karjadi. Kitab UndangUndang Hukum Acara Pidana Dengan 
Penjelasan Resmi Dan Komentar. Bogor: Politeia, 1997.

Suharyo, Suharyo. "Aspek Hukum Surat Keterangan Dokter Dalam Sistem Peradilan Pidana (Pemberantasan Tindak Pidana Korupsi pada Era Covid-19).” Jurnal Penelitian Hukum De Jure 20, no. 3 (September 29, 2020): 363.

Suharyo. "The Prospect of the Existence of National Criminal Code in a Democratic State in Indonesia during the Covid-19 Pandemic." Jurnal Penelitian Hukum De Jure 21, no. 3 (September 28, 2021): 285.

Susanto, Mei, and Teguh Tresna Puja Asmara. "Ekonomi versus Hak Asasi Manusia dalam Penanganan Covid-19: Dikotomi atau Harmonisasi." Jurnal HAM 11, no. 2 (August 28, 2020): 301.

Zainuddin, Muhmmad, and Siti Nur Umariyah Febriyanti. "Perlindungan Hukum Terhadap Relawan Uji Klinis Vaksin Covid-19." Jurnal Ilmiah Dunia Hukum (2021): 134-142.

"Coronavirus Disease (COVID-19) - World Health Organization." Accessed August 13, 2021. https://www.who.int/emergencies/ diseases/novel-coronavirus-2019.

"Natalius Pigai: Menolak Vaksin Covid-19 Itu Hak Asasi Rakyat." suara.com. Last modified January 12, 2021. Accessed August 12, 2021. https://hits.suara.com/ $\mathrm{read} / 2021 / 01 / 12 / 172951 /$ natalius-pigaimenolak-vaksin-covid-19-itu-hak-asasirakyat.

"Negara-negara yang telah memulai vaksinasi Covid-19." BBC News Indonesia, n.d. Accessed August 14, 2021. https://www.bbc. com/indonesia/dunia-55394914. 


\section{HALAMAN KOSONG}

